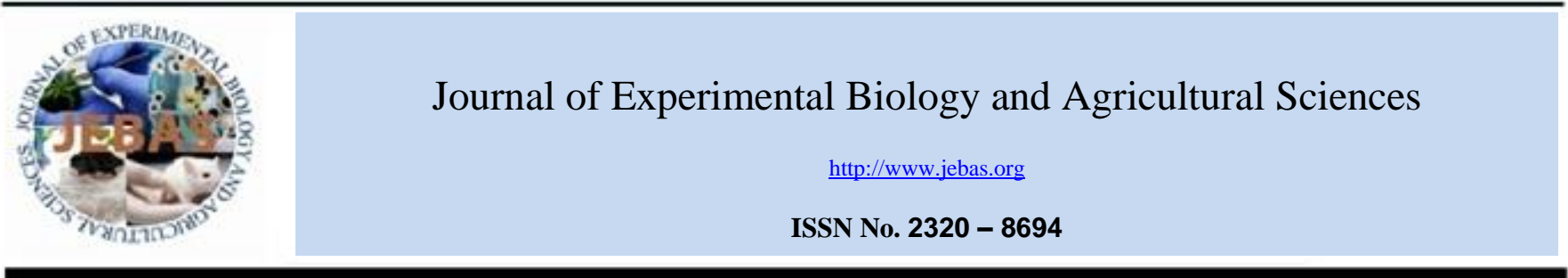

\title{
MAIZE PRODUCTION STRATEGY IN SAUDI ARABIA
}

\section{Othman S. Al nashwan, Khalid N. Al rwis, Adel M. Ghanem, Sharaf El-din B. Ahamed*, Nageeb M. Aldawdahi}

Department of Agricultural Economics, College of Food and Agricultural Sciences, King Saud University, P.O. Box 2460 , Riyadh 11451.

Received - August 20, 2019; Revision - October 28, 2019; Accepted - November 29, 2019

Available Online - December 25, 2019

DOI: http://dx.doi.org/10.18006/2019.7(6).543.553

\section{KEYWORDS \\ Maize \\ Productivity \\ Strategy \\ Economic guidance \\ Linear programming}

\begin{abstract}
This study develops a strategy for the production of maize in Saudi Arabia by examining the current situation, determining priority regions, and providing economic guidance for land resources used in maize production. This study uses the methodology of point estimation and linear programming. The results of study suggested that current maize production is concentrated only in the Arabian Shield areas (Makkah, Madinah, Jazan, Asir, Najran, and Al Baha), which are low productivity areas. The share of cultivated area and maize production in these areas is $86.51 \%$ and $79.13 \%$, respectively. Further, result of study revealed that Hail ranked first among priority regions for maize production, this was followed by Qassim, Al-Jawf, Riyadh, and Sharqia. Result of study also suggested that economic guidancefor land resources of 17,840 hectares derived using linear programming leads to a decrease in water use by $37.7 \%$, an increase in maize production by $79.95 \%$, a decrease in the quantity of imports by $1.9 \%$, and an increase in the self-sufficiency ratio from $2.32 \%$ to $4.16 \%$. Result of study recommends that Ministry of Environment, Water and Agriculture review the policy of maize production by shifting maize cultivation to areas with high and medium productivity in priority regions and considering economic guidance for land resources used in maize production.
\end{abstract}

* Corresponding author

E-mail: salaagib@ksu.edu.sa (Sharaf El-din B. Ahamed)

Peer review under responsibility of Journal of Experimental Biology and Agricultural Sciences.

Production and Hosting by Horizon Publisher India [HPI] (http://www.horizonpublisherindia.in/).

All rights reserved.
All the articles published by Journal of Experimental Biology and Agricultural Sciences are licensed under a Creative Commons Attribution-NonCommercial 4.0 International License Based on a work at www.jebas.org.

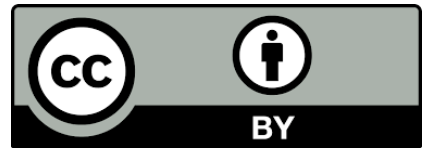




\section{Introduction}

Maize, a summer cereal, has high economic importance, and is used as food and feed in Saudi Arabia, with a production of 93.9 thousand tons, available consumption of 1.58 million tons, and a self-sufficiency rate of $5.9 \%$ in 2016 . Given the inability of domestic production to fully meet the consumption needs of maize, the country has been forced to rely on imports. The Kingdom of Saudi Arabia imported 1.49 million tons valued at $\$ 319.23$ million representing $1.66 \%$ of the value of agricultural imports amounting to $\$ 19.28$ billion in 2016 (Arab Organization for Agricultural Development, 2017). Maize cultivation is currently concentrated in low productivity areas (Makkah, Madinah, Jazan, Najran, and Al baha). The total area planted with maize crops in these regions was 15,440 hectares, representing $86.51 \%$ of the agricultura cultivation. While relative importance of maize area in high productivity area is only $13.5 \%$ of the total area planted $(17.84$ thousand hectares) with maize crop in 2015 (General Authority for Statistics, 2015). Low productivity does not allow for comparative advantage in production due to high losses in agricultural resources used, which leads to increase maize production costs in low productivity areas. Thus, a strategy is required to reorient the land resources used in maize production in the Kingdom of Saudi Arabia.

Various previously conducted studies have examined the economics of maize production. Fufa \& Hassan (2003) estimated a stochastic maize production technology and carried out a production risk analysis for maize farmers in Ethiopia. Results of this study suggested that improved maize technology exhibits constant returns to scale, whereas non-adopters use a technology with decreasing returns to scale. The study showed that timely planting is critical for stable maize yield among both adopters and non-adopters. Nevertheless, the results showed that factors which are under the control of farmers do not sufficiently explain maize yield variability compared to natural factors such as rainfall, frost, pests, and diseases. According to the report of Arab Organization for Agricultural Development (2006), the average yield of maize for irrigated land in the Arab world was 4.63 ton/ha, while it was reported 8.15 ton/ha for developed countries. The low productivity of maize in the Arab world is attributed to the traditional pattern of agriculture, small size of agricultural tenure and dispersion, low use of production inputs, lack of agricultural techniques, weak extension capacity, absence of marketing services and natural constraints.

Abbas \& Al-Akili (2015) studied the costs of maize production in the Babil province of Iraq. The variable production costs of both domestic and hybrid seed varieties accounted for $91.64 \%$ and $95.47 \%$ of the total cost, respectively. There are also significant differences between the local and hybrid seed varieties in terms of productivity, costs, and total income. The average farm area for both local and hybrid seed was estimated to be 8.96 and 4.95 ha, respectively. Uya et al. (2015) assessed the impact of factors on adaptation to drought formaize production in the Dakrong district, Vietnam. They found that increasing household's capitals, experience, maize production scale, gender and non-farm income significantly increased the probability of applying at least one adaptation measure in maize production. Similarly, Zhang et al. (2017) reported that combination of drip irrigation, plastic film mulching, and increased planting density improved final maize yield in Xinjiang. Maximum economic return and the irrigation level were linearly related to the price of water.

This study was conducted to develop a strategy for maize production by determining priority regions and economic guidancefor land resources by using the point estimation and linear programming methodology.

Study undertaken issues related to the current status of maize production in Saudi Arabia in 2015, disparities in productivity among the regions, the prioritization of regions in maize production, economic guidance for land resources used in maize production, and an analysis of the sensitivity to changes in productivity and specific resource constraints for maize production in Saudi Arabia.

\section{Materials and Methods}

This study is based on dividing the maize production areas into three productivity categories based on the range (the difference between the largest and the smallest values) and the number of categories using the rule given by Thomas \& Pawel (2006) $2.5 \times$ $\sqrt[4]{\mathrm{n}}$. The length of the category was calculated by dividing the range by the number of categories. Priority regions in the production of maize based on the scoring technique according to several criteria (Blank \& Tarquin, 1989) such as (1) water needs of maize, (2) average productivity per hectare, (3) water use efficiency (WUE) in maize production, (4) the relative importance of the maize cultivation area in the different regions, and (5) relative importance of the total crop area. The first four criteria reflect the production and environmental characteristics and the importance of the crop from the farmers' perspective, and the fifth criterion reflects the efficiency of volume or capacity of the production areas. An area gradient of zero to 100 was used, the grades were obtained and prioritized by maize that were collected and prioritized. This study, in planning the maize production strategy for the different production areas, was based on the economic orientation of the cultivated area in the light of the priority of the production areas, which were determined by the method of scoring technique according to the mentioned criteria. Cultivated areas were distributed in light of the relative importance of the points obtained by each area. The method of point estimation was used in the study of the proposed crop composition 
of Saudi Arabia in 2017 (Ministry of Environment, Water and Agriculture, 2017).

This study is based on the economic guidance for land resources used in maize production based on priorities identified in the point estimation method (i.e., the points obtained by each region as follows):

Average share per point of maize area $=$ total area planted by maize crop $\div$ total number of points for maize production areas

Area planted with maize crop in each region = average share per point of maize area $\times$ number of points for production area

Economic guidance for land resources in the linear programming model was also adopted in present study, this model can be expressed as follows (Bector \& Chandra, 2005):

$\operatorname{Max} \mathrm{Z}=\mathrm{C} X$

s.t.

$\mathrm{A} X \leq \mathrm{b}$,

$X \geq 0$,

Where $\mathrm{Z}$ is the value of the maximizing function, which is to maximize the local maize production given the resource constraints, the most important of which are land and water resources. C represents an $n \times 1$ vector for the productivity of the earth unit (hectare). $\mathrm{X}$ represents an $n \times 1$ vector of the 11 production regions. A represents a matrix of technical transactions of the rank $(m \times n)$. A sensitivity analysis, called the postoptimization analysis, was carried out to determine the degree of response of the optimal solution, or the elasticity of the proposed production areas to the expected changes in the productivity of the ground unit (hectare) and the resource determinants. Finally, detailed results of the agricultural census conducted by the General Authority for Statistics (2015) was used, in addition to specialized studies in assessing the water needs of crops in the different production areas.

Linear programming is one of the most important methods used in determining the optimal plan for the distribution of cultivated areas. It was used in studying the future plan for Saudi agriculture in 2004. It was also used in the study of the expected crop composition in the light of water and food security considerations of Saudi Arabia (Ghanem et al., 2010). Finally, this study relied on the detailed results of the agricultural census conducted by the General Authority for Statistics in 2015, in addition to the specialized studies in estimating the water needs of different crops, the most important of which is the Hussain et al. (2010).

\section{Results and discussion}

\subsection{The current situation of maize production in Saudi Arabia}

Table 1 represents the current status of maize production in the various regions of the Kingdom of Saudi Arabia in 2015. It shows that the area planted with maize have 17843 hectares, while total maize production was 63350 tons with a value of 77.34 million

Table 1 Relative importance of the area and production of maize in different regions in 2015

\begin{tabular}{|c|c|c|c|c|}
\hline Region & Area (hectares) & $\%$ & $\begin{array}{l}\text { Production (thousand } \\
\text { tons) }\end{array}$ & $\%$ \\
\hline Riyadh & 589 & 3.30 & 2.69 & 4.25 \\
\hline Eastern region & 4 & 0.02 & 0.02 & 0.03 \\
\hline Qassim & 489 & 2.74 & 2.26 & 3.57 \\
\hline Al-Jawf & 221 & 1.24 & 1.02 & 1.61 \\
\hline Hail & 1105 & 6.19 & 7.22 & 11.41 \\
\hline Makkah & 5436 & 30.47 & 18.37 & 29.00 \\
\hline Madina El Monawara & 12 & 0.07 & 0.04 & 0.06 \\
\hline Jazan & 2306 & 12.92 & 6.64 & 10.47 \\
\hline Asir & 5365 & 30.07 & 17.76 & 28.03 \\
\hline Najran & 17 & 0.10 & 0.06 & 0.09 \\
\hline Al Baha & 2299 & 12.88 & 7.26 & 11.47 \\
\hline Kingdom & 17843 & 100 & 63.35 & 100 \\
\hline
\end{tabular}

Source: General Authority for Statistics, detailed results of the agricultural census for 2015.

Journal of Experimental Biology and Agricultural Sciences http://www.jebas.org 
riyals. Maize production is concentrated in five productive areas i.e. Makkah Al Mukarramah (29\%), Asir (28.03\%), Al Baha (11.47\%), Hail (11.41\%), and Jazan (10.47\%). The relative importance of the production of the above-mentioned areas is $90.38 \%$, while the contribution of the rest of the productive areas does not exceed $9.62 \%$.

\subsection{Disparities in maize productivity in the different regions}

Productivity is a measure of the efficiency of converting agricultural resources into a final output (i.e., the ability to convert inputs to outputs according to specific conditions at a certain cost over a specified period of time). Productivity can also defined as amount produced by one unit of production and it is calculated by dividing maize production by the cultivated area (Suleiman, 2014).The productivity index can be expressed as follows:

Productivity index $=($ comparative productivity area $\div$ base area productivity) $\times 100$.

It is clear from Table 2 that maize productivity ranged from a minimum of 2.88ton/ha in Jazan region to a maximum of 6.53 ton/ha in the Hail region with an average of 3.55 ton/ha in 2015 . This index was used to determine the extent of variation in maize productivity among regions.

In current study, index of maize productivity was calculated by taking the productivity of the Jazan region as 100 percent since it is the lowest in terms of maize productivity. From table 2 it is clear that all regions have higher productivity compared to the Jazan region ranging from a minimum of $9.7 \%$ for the $\mathrm{Al}$ Baha region to a maximum of $126.7 \%$ for the Hail region. To compare the productivity of the regions with the average productivity at the Kingdom level, the calculation of the index shows that the productivity of Riyadh, Eastern region, Qassim, Al-Jawf, and Hail exceeds the average productivity in the Kingdom by $28.7 \%$, $40.8 \%, 30.1 \%, 30.1 \%, 83.9 \%$, respectively. The productivity of the some regions was lower than the average productivity of Kingdom and it ranging from a minimum of $0.6 \%$ for Najran to a maximum of $18.9 \%$ for Jazan in 2015 . The disparity in maize productivity among the regions is due to the variation in agricultural fertility, water quality, irrigation, temperature, humidity, rainfall, as well as the experience of the maize farmers.

By dividing maize production areas into different productive categories (Table 3), results of study revealed that areas of the Arabian Shield (Makkah, Madinah, Jazan, Asir, Najran, and Al Baha) are in the low productivity category (less than 3.68 ton/ha), while the share of cultivated area and maize production in low productivity category reached $86.51 \%$ and $79.13 \%$, respectively. Riyadh, Eastern region, Qassim, and Al-Jawf are in the medium productivity category (3.68 ton/ha and more but less than 6.09 ton/ha) while the share of cultivated area and maize production in the average productivity area was $7.3 \%$ and $9.46 \%$, respectively. In the highest productivity category, only Hail region (6.09 ton/ha and more) was considered, where the area of cultivated area and maize production was $6.19 \%$ and $11.41 \%$, respectively.

Table 2 The extent of inequality in maize productivity for different regions in 2015

\begin{tabular}{|c|c|c|c|c|c|}
\hline Region & $\begin{array}{c}\text { Yield } \\
\text { (tons / ha) }\end{array}$ & $\begin{array}{l}\text { Productivity index } \\
(\text { Jazan region }=100)\end{array}$ & $\begin{array}{l}\text { Rate of change in } \\
\text { productivity } \%\end{array}$ & $\begin{array}{l}\text { Productivity index } \\
\text { (Kingdom = 100) }\end{array}$ & $\begin{array}{l}\text { Rate of change in } \\
\text { productivity } \%\end{array}$ \\
\hline Riyadh & 4.57 & 158.7 & 58.7 & 128.7 & 28.7 \\
\hline Eastern region & 5.00 & 173.6 & 73.6 & 140.8 & 40.8 \\
\hline Qassim & 4.62 & 160.4 & 60.4 & 130.1 & 30.1 \\
\hline Al-Jawf & 4.62 & 160.4 & 60.4 & 130.1 & 30.1 \\
\hline Hail & 6.53 & 226.7 & 126.7 & 183.9 & 83.9 \\
\hline Makkah & 3.38 & 117.4 & 17.4 & 95.2 & -4.8 \\
\hline $\begin{array}{l}\text { Madina El } \\
\text { Monawara }\end{array}$ & 3.33 & 115.6 & 15.6 & 93.8 & -6.2 \\
\hline Jazan & 2.88 & 100 & - & 81.1 & -18.9 \\
\hline Asir & 3.31 & 114.9 & 14.9 & 93.2 & -6.8 \\
\hline Najran & 3.53 & 122.6 & 22.6 & 99.4 & -0.6 \\
\hline Al Baha & 3.16 & 109.7 & 9.7 & 89.0 & -11.0 \\
\hline Kingdom & 3.55 & 123.3 & 23.3 & 100 & - \\
\hline
\end{tabular}

Source: Compiled and calculated from data in Table 1. 
Table 3 Distribution of maize production areas to different productivity categories

\begin{tabular}{|c|c|c|c|c|c|}
\hline Productivity Category & Regions & Area (ha) & $\%$ & $\begin{array}{l}\text { Local production } \\
\text { per thousand tons }\end{array}$ & $\%$ \\
\hline \multicolumn{6}{|l|}{ Low } \\
\hline Less than 3.68 ton/ha & $\begin{array}{l}\text { Makkah, Madinah, Jazan, Asir, } \\
\text { Najran, and Al-Baha }\end{array}$ & 15,435 & 86.51 & 50.13 & 79.13 \\
\hline \multicolumn{6}{|l|}{ Medium } \\
\hline $\begin{array}{l}3.68 \text { ton } / \text { ha and more but } \\
\text { less than } 6.09 \text { ton/ha }\end{array}$ & $\begin{array}{l}\text { Riyadh, Eastern region, Qassim, } \\
\text { and Al-Jawf }\end{array}$ & 1,303 & 7.30 & 5.99 & 9.46 \\
\hline \multicolumn{6}{|l|}{ High } \\
\hline 6.09 ton/ha and more & Hail & 1,105 & 6.19 & 7.22 & 11.41 \\
\hline Total & & 17,843 & 100 & 63.35 & 100 \\
\hline
\end{tabular}

Source: Table 2.

Table 4 Criteria for determining priority areas for maize production in Saudi Arabia, 2015

\begin{tabular}{|c|c|c|c|c|c|}
\hline Region & $\begin{array}{l}\text { Productivity } \\
\text { ton/ha }\end{array}$ & $\begin{array}{l}\text { Water needs } \\
\text { Thousand } \mathrm{m}^{3} / \mathrm{ha}\end{array}$ & $\begin{array}{c}\text { Water use } \\
\text { efficiency } \\
\text { ton/thousand } \mathrm{m}^{3}\end{array}$ & $\begin{array}{l}\text { Relative importance } \\
\text { of maize area)(\% }\end{array}$ & $\begin{array}{l}\text { Relative importance } \\
\text { of cropland) } \%\end{array}$ \\
\hline Riyadh & 4.57 & 11.28 & 0.41 & 3.30 & 27.4 \\
\hline Eastern region & 5.00 & 7.35 & 0.68 & 0.02 & 7.2 \\
\hline Qassim & 4.62 & 7.03 & 0.66 & 2.74 & 13.8 \\
\hline Al-Jawf & 4.62 & 7.35 & 0.63 & 1.24 & 19.9 \\
\hline Hail & 6.53 & 6.91 & 0.95 & 6.19 & 11.1 \\
\hline Makkah & 3.38 & 16.13 & 0.21 & 30.47 & 5.34 \\
\hline Madina El Monawara & 3.33 & 11.28 & 0.30 & 0.07 & 2.31 \\
\hline Jazan & 2.88 & 11.47 & 0.25 & 12.92 & 5.55 \\
\hline Asir & 3.31 & 8.44 & 0.39 & 30.07 & 2.20 \\
\hline Najran & 3.53 & 11.00 & 0.32 & 0.10 & 0.51 \\
\hline Al Baha & 3.16 & 10.08 & 0.31 & 12.88 & 0.48 \\
\hline
\end{tabular}

Source: General Authority for Statistics, detailed results of the agricultural census for 2015

\subsection{Determining maize production priority regions}

Priority regions for maize production have been identified through the criteria in Table 4 . Result of study revealed that (i) per hectare productivity ranging from a minimum of 2.88 ton/ha in the Jazan region to a maximum of $6.53 \mathrm{ton} / \mathrm{ha}$ in the Hail region, (ii) water requirement of maize ranging from a minimum of 6.91 thousand $\mathrm{m}^{3} / \mathrm{ha}$ in the Hail region to a maximum of $16,130 \mathrm{~m}^{3} /$ ha in the Makkah region, (iii) water use efficiency expressed as the average productivity of the water unit ranging from a minimum of 0.21 ton/thousand $\mathrm{m}^{3}$ in the Makkah region to a maximum of 0.95 ton/thousand $\mathrm{m}^{3}$ in the Hail region, (iv) the relative importance of the area planted with maize, which ranged from a minimum of $0.02 \%$ for the eastern region to a maximum of $30.47 \%$ for the Makkah region and (v) the relative importance of the cropland area ranging from a minimum of $0.48 \%$ for the $\mathrm{Al}$ Baha region to a maximum of $27.4 \%$ for the Riyadh region.

A composite standard was used to combine the results of the criteria using the scoring technique. It is clear from Table 5 that the prioritization of the regions in maize production based on the results of the combined criteria places the Hail region in first place, followed by Qassim, Al-Jawf, Riyadh and Eastern region (tied for fourth place), Makkah, Jazan, and Najran and Al Baha (tied for seventh place), and Medina, ranked last. 
Table 5 Results applying the criteria for determining priority areas in maize production in Saudi Arabia

\begin{tabular}{|c|c|c|c|c|c|c|c|}
\hline Region & $\begin{array}{l}\text { Productivity } \\
\text { Of the ground } \\
\text { unit }\end{array}$ & Water needs & $\begin{array}{l}\text { Water use } \\
\text { efficiency }\end{array}$ & $\begin{array}{c}\text { Relative } \\
\text { importance of } \\
\text { maize area }\end{array}$ & $\begin{array}{l}\text { Relative } \\
\text { importance of } \\
\text { crop area }\end{array}$ & $\begin{array}{l}\text { Total } \\
\text { points }\end{array}$ & $\begin{array}{c}\text { Arrangement } \\
\text { areas }\end{array}$ \\
\hline Riyadh & 60 & 20 & 60 & 50 & 100 & 290 & 4 \\
\hline Eastern region & 80 & 60 & 90 & 0 & 60 & 290 & 4 \\
\hline Qassim & 70 & 70 & 80 & 40 & 80 & 340 & 2 \\
\hline Al-Jawf & 70 & 60 & 70 & 30 & 90 & 320 & 3 \\
\hline Hail & 90 & 80 & 100 & 60 & 70 & 400 & 1 \\
\hline Makkah & 40 & 0 & 0 & 100 & 40 & 180 & 6 \\
\hline $\begin{array}{l}\text { Madina El } \\
\text { Monawara }\end{array}$ & 30 & 20 & 20 & 10 & 30 & 110 & 8 \\
\hline Jazan & 0 & 10 & 10 & 80 & 50 & 150 & 7 \\
\hline Asir & 20 & 50 & 50 & 90 & 20 & 230 & 5 \\
\hline Najran & 50 & 30 & 40 & 20 & 10 & 150 & 7 \\
\hline Al Baha & 10 & 40 & 30 & 70 & 0 & 150 & 7 \\
\hline
\end{tabular}

Source: Table 4 .

Table 6 Economic guidance for land resources based on prioritization of areas in the point estimation method

\begin{tabular}{|c|c|c|c|c|c|c|}
\hline \multirow{2}{*}{ Region } & \multirow{2}{*}{$\begin{array}{l}\text { Proposed area } \\
\text { in hectare }\end{array}$} & \multirow{2}{*}{$\%$} & \multicolumn{2}{|c|}{ Quantity of water used in million $\mathrm{m}^{3}$} & \multicolumn{2}{|c|}{ Production of maize in thousand tons } \\
\hline & & & Current situation & Proposed & Current situation & Proposed \\
\hline Riyadh & $1,982.6$ & 11.11 & 6.64 & 22.36 & 2.69 & 9.06 \\
\hline Eastern region & $1,982.6$ & 11.11 & 0.03 & 14.57 & 0.02 & 9.91 \\
\hline Qassim & $2,324.4$ & 13.03 & 3.44 & 16.34 & 2.26 & 10.74 \\
\hline Al-Jawf & $2,187.6$ & 12.26 & 1.62 & 16.08 & 1.02 & 10.11 \\
\hline Hail & $2,734.6$ & 15.33 & 7.64 & 18.90 & 7.22 & 17.86 \\
\hline Makkah & $1,230.6$ & 6.90 & 87.68 & 19.85 & 18.37 & 4.16 \\
\hline $\begin{array}{l}\text { Madina El } \\
\text { Monawara }\end{array}$ & 752.0 & 4.21 & 0.14 & 8.48 & 0.04 & 2.50 \\
\hline Jazan & $1,025.5$ & 5.75 & 26.45 & 11.76 & 6.64 & 2.95 \\
\hline Asir & $1,572.4$ & 8.81 & 45.28 & 13.27 & 17.76 & 5.20 \\
\hline Najran & $1,025.5$ & 5.75 & 0.19 & 11.28 & 0.06 & 3.62 \\
\hline Al Baha & $1,025.5$ & 5.75 & 23.17 & 10.34 & 7.26 & 3.24 \\
\hline Total & 17,843 & 100 & 202.28 & 163.23 & 63.35 & 79.36 \\
\hline
\end{tabular}

Source: Tables 1 and 5.

\subsection{Economic guidance for land resources used in maize production}

The economic guidance for the land resources used in the production of maize was based on the prioritization of areas in the point estimation method presented earlier. Table 6 shows that the area proposed for maize crop cultivation is 17,840 hectares. It is concentrated in several areas, of which the most important are Hail (15.33\%), Qassim (13.03\%), Al-Jawf (12.26\%), Riyadh (11.11\%), Asir $(8.81 \%)$, and Makkah $(6.90 \%)$. The relative importance of the proposed area of maize in Jazan, Najran, and Al Baha area was $5.75 \%$ in the three

Journal of Experimental Biology and Agricultural Sciences http://www.jebas.org 
regions, followed by Al Madinah Al Munawwarah (4.21\%) The economic guidance for land resources in the point estimation method reduces the amount of water used in maize production from 202.28 million $\mathrm{m}^{3}$ to 163.23 million $\mathrm{m}^{3}$, decreasing by $19.3 \%$, while domestic production of maize increases from 63,350 tons to 79,360 tons at a rate of $25.3 \%$. Under the proposed economic guidance, average maize productivity is estimated at 4.45 ton/ha, which is 0.9 ton/ha over 3.55 ton/ha,the average productivity under the current situation.

The economic guidance for land resources was also carried out using a linear programming model, which consists of the objective function that is optimized for maize production under resource constraints, the most important of which are land and water resources. The first is the existing area with maize plantations at the level of the Kingdom, while the second to sixth relate to the possibility of expanding the cultivated land in areas with medium to high productivity (Riyadh, Eastern region, Qassim, Juff, and Hail).The seventh restriction relates to the possibility of reducing the cultivation of maize in areas with low productivity (Makkah, Madinah, Jazan, Asir, Najran, and $\mathrm{Al}$ Baha). Restrictions on water resources can be expressed in the eighth restriction as the possibility of reducing the amount of water used in maize production. A linear programming model using the following equations was formulated:

\begin{tabular}{|c|c|}
\hline \multicolumn{2}{|l|}{ s.t. } \\
\hline 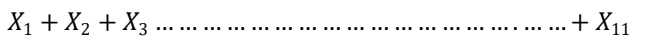 & $=17,843$ \\
\hline$X_{1}$ & 589 \\
\hline$X_{2}$ & $\geq$ \\
\hline$X_{3}$ & 489 \\
\hline$X_{4}$ & $\geq$ \\
\hline$X_{5}$ & 1,105 \\
\hline$X_{6}+X_{7}+X_{8}+X_{9}+X_{10}+X_{11}$ & $\leq 15,435$ \\
\hline $\begin{array}{l}11.28 X_{1}+7.35 X_{2}+7.03 X_{3}+7.35 X_{4}+6.91 X_{5}+16.13 X_{6} \\
+11.28 X_{7}+11.47 X_{8}+8.44 X_{9}+11.0 X_{10}+10.08 X_{11}\end{array}$ & $\leq 202,280$ \\
\hline
\end{tabular}

It is clear from the results of the linear programming in Tables 7 and 8 that the area proposed for maize crop cultivation is 17840 hectares, of which 16540 hectares are allocated to Hail, and about 589, 489, 221 and 4 hectares are allocated for the Riyadh, Qassim, Al-Jawf, and Eastern region respectively. The proposed economic directive requires the use of 126.03 million $\mathrm{m}^{3}$ of water, representing $62.3 \%$ of the available water $\left(202.28\right.$ million $\left.\mathrm{m}^{3}\right)$,

Table7 Cultivated area, production, and sensitivity analysis of productivity change in the proposed guidance

\begin{tabular}{|c|c|c|c|c|c|c|c|}
\hline \multirow{2}{*}{ Region } & \multirow{2}{*}{$\begin{array}{l}\text { Productivity } \\
\text { per ton }\end{array}$} & \multicolumn{2}{|c|}{ Area cultivated hectare } & \multicolumn{2}{|c|}{$\begin{array}{l}\text { Local production per thousand } \\
\text { tons }\end{array}$} & \multicolumn{2}{|c|}{$\begin{array}{l}\text { The range of productivity } \\
\text { change of the ground unit }\end{array}$} \\
\hline & & $\begin{array}{l}\text { Current } \\
\text { situation }\end{array}$ & Proposed & $\begin{array}{c}\text { Current } \\
\text { situation }\end{array}$ & Proposed & minimum & maximum \\
\hline Riyadh & 4.57 & 589 & 589 & 2.69 & 2.69 & - & 6.53 \\
\hline Eastern region & 5.00 & 4 & 4 & 0.02 & 0.02 & - & 6.53 \\
\hline Qassim & 4.62 & 489 & 489 & 2.26 & 2.26 & - & 6.53 \\
\hline Al-Jawf & 4.62 & 221 & 221 & 1.02 & 1.02 & - & 6.53 \\
\hline Hail & 6.53 & 1,105 & 16,540 & 7.22 & 108.01 & 5.0 & - \\
\hline Makkah & 3.38 & 5,436 & - & 18.37 & - & - & 6.53 \\
\hline $\begin{array}{l}\text { Madina El } \\
\text { Monawara }\end{array}$ & 3.33 & 12 & - & 0.04 & - & - & 6.53 \\
\hline Jazan & 2.88 & 2,306 & - & 6.64 & - & - & 6.53 \\
\hline Asir & 3.31 & 5,365 & - & 17.76 & - & - & 6.53 \\
\hline Najran & 3.53 & 17 & - & 0.06 & - & - & 6.53 \\
\hline Al Baha & 3.16 & 2,299 & - & 7.26 & - & - & 6.53 \\
\hline Total & - & 17,843 & 17,843 & 63.35 & 114.00 & - & - \\
\hline
\end{tabular}

Journal of Experimental Biology and Agricultural Sciences http://www.jebas.org 
Table8 Available, used and surplus economic determinants and resources and sensitivity analysis of the change in the resource constraints used in the proposed guidance

\begin{tabular}{|c|c|c|c|c|c|c|}
\hline Determinants of resource & Available & The used & $\begin{array}{c}\text { Surplus and } \\
\text { deficit }\end{array}$ & $\begin{array}{c}\text { Used to } \\
\text { Available \% }\end{array}$ & \multicolumn{2}{|c|}{$\begin{array}{l}\text { The range of resource change } \\
\text { minimum maximum }\end{array}$} \\
\hline $\begin{array}{l}\text { Total area of maize in } \\
\text { hectare }\end{array}$ & 17,843 & 17,843 & - & 100 & 2,408 & $28,878.2$ \\
\hline \multicolumn{7}{|c|}{ Areas of high productivity per hectare: } \\
\hline Hail & 1,105 & 16,540 & $-15,435$ & & 0 & 16,540 \\
\hline \multicolumn{7}{|c|}{ Areas of medium productivity per hectare: } \\
\hline Riyadh & 589 & 589 & - & 100 & - & 16,024 \\
\hline Eastern region & 4 & 4 & - & 100 & - & 15,439 \\
\hline Qassim & 489 & 489 & - & 100 & - & 15,924 \\
\hline Al-Jawf & 221 & 221 & - & 100 & - & 15,656 \\
\hline \multicolumn{7}{|c|}{ Areas of low productivity per hectare: } \\
\hline Makkah & 5,436 & - & 5,436 & - & - & - \\
\hline Madina El Monawara & 12 & - & 12 & - & - & - \\
\hline Jazan & 2,306 & - & 2,306 & - & - & - \\
\hline Asir & 5,365 & - & 5,365 & - & - & - \\
\hline Najran & 17 & - & 17 & - & - & - \\
\hline Al Baha & 2,299 & - & 2,299 & - & - & - \\
\hline $\begin{array}{l}\text { Water resources } \\
\text { million } \mathrm{m}^{3}\end{array}$ & 202.28 & 126.03 & 76.25 & & 126.03 & - \\
\hline
\end{tabular}

Source: Linear programming results using the Linear Interactive and Discrete Optimizer (Lindo) software.

leaving a surplus water resource of 76.25 million $\mathrm{m}^{3}$. The total production of maize according to the proposed economic guidance is 114,000 tons. Thus, under the proposed economic guidance total production will increase by 50,650 tons $(79.95 \%)$. Further, under such guidance, the average productivity per hectare is estimated to be 6.39 ton/hectare, while it is 3.55 ton/ha in current situation. Thus, the average productivity per hectare of maize in the proposed economic guidance is higher than the current situation of 2.84 ton/ha.

A sensitivity analysis of the linear programming model was carried out to determine the robustness of the solution to changes in both productivity and resource determinants that are required by production conditions, and to determine the extent to which these changes can be adapted to without changing the proposed routing pattern or optimal solution of the linear programming model. As for the changes in the productivity of the land unit (hectare), it is clear from table 7 that productivity in Hail can be reduced minimally, while maize production in other regions can be increased only in maximum limits without changing the pattern under the proposed guidance. As for the changes that may occur in the resource determinants, it is clear from table 8 that the total area under maize production can be reduced minimally. The other determinants related to maize cultivation in Hail, Riyadh, and Eastern region, increase in maximum limits only. Finally, with regard to the water resource determinant, it was found that the quantity used can only be reduced minimally without changing the proposed pattern of guidance.

\section{Conclusion}

Results of current study revealed that there is a flaw in the production policy of maize. Production is concentrated in the Arabian Shield areas (Makkah, Madinah, Jazan, Asir, Najran, and Al Baha). The low productivity of the Arab Shield area makes it impossible to achieve comparative advantage, in addition to wasting agricultural resources used in maize production. By determining priority regions and economic guidance for land resources using linear programming, it was found that the total production area planted with maize can increase by $79.95 \%$ and the quantity of water used can decrease by $37.7 \%$. The application of the proposed economic directive by using linear programming 
demonstrates an increase in production to replace the amount of imports (i.e., reducing the amount of Saudi imports from 2.67 million tons to 2.62 million tons or by $1.9 \%$ ). Given the local consumption of 2.74 million tons of maize, implementation of the proposed economic guidance leads to increasing the selfsufficiency of maize from $2.32 \%$ to $4.16 \%$. The results of this study suggest that the Ministry of Environment, Water, and Agriculture review the policy of maize production by shifting maize cultivation into areas with high and medium productivity in priority regions and considering economic guidance for land resources used in maize production.

\section{Acknowledgement}

The authors would like to acknowledge the Deanship of Scientific Research at King Saud University through the College of Food and Agricultural Sciences - Research Center for funding this work. The authors are also grateful to the Deanship of Scientific Research at King Saud University for their technical support.

\section{Conflict of Interest}

The authors declare that they have no conflict of interest.

\section{References}

Abbas NK, Osamah KA (2015) An Estimation of Cost Function of Maize in Iraq- Babil Province (As Case Study) Season 2013. Iraqi Journal of Agricultural Sciences 46: 559-568.

Arab Organization for Agricultural Development (2006) National Analytical Study for the Development of Maize Production in the Arab World. Khartoum, Sudan.

Arab Organization for Agricultural Development (2017) Annual Report of Arab Agricultural StatisticsVolume37. Khartoum, Sudan.

Bector CR, Chandra S (2005) Fuzzy Mathematical Programming and Fuzzy Matrix Games. Springer-Verlag Berlin Heidelberg, New York,

Blank LT, Tarquin AJ(1989) Engineering Economy, Third Edition.
McGrow- Hill Book Company, New York.

Fufa B, Hassan RM (2003) Stochastic maize production technology and production risk analysis in Dadar district, East Ethiopia. Agrekon 42: 116-128.

General Authority for Statistics (2015) Detailed results of the agricultural census for the year 2015.Saudi Arabia.

Ghanem, Adel Khalifa and Sahar Abdel MoneimKamra (2010) Projected crop composition in the light of water and food security considerations of Saudi Arabia, Conference of the strategy of agricultural development and challenges of Egyptian food security, Faculty of Agriculture, Alexandria University, held on 28-29 July, 2010 at Alexandria University, Egypt.

Hussain G, Alquwaizany A, Al-Zarah A (2010) Guidelines for Irrigation Water Quality and Water Management in The Kingdom of Saudi Arabia: An Overview. Journal of Applied Sciences 10: 79-96. DOI: 10.3923/jas.2010.79.96.

Ministry of Environment, Water and Agriculture (2017) Study of Crop Structure in Saudi Arabia.

Suleiman AA (2014) Agricultural Production Economics. Amman, Jordan: Dar Zahran Publishing and Distribution.

Thomas H, Pawel L (2006) Statistics: Methods and Applications Comprehensive Reference for Science, Industry, and Data Mining. Tulsa, OK: StatSoft. Inc.

Uya TC, Limnirankul B, Chaovanapoonphol Y(2015) Factors Impact on Farmers' Adaptation to Drought in Maize Production in Highland Area of Central Vietnam.In: 1st International Conference on Asian Highland Natural Resources Management. Agriculture and Agricultural Science Procedia, 5:75 - 82.

Zhang G, Liu C, Xiao C, Xie R, Ming B, Hou P, Liu G, Xu W, Shen D, Wang K, Li S (2017) Optimizing water use efficiency and economic return of super high yield spring maize under drip irrigation and plastic mulching in arid areas of China.Field Crops Research 211:137-146. 